\title{
Weather, Soil and 2,4-D Effects on Tallgrass Prairie in Oklahoma
}

\author{
J. POWELL, J.F. STRITZKE, R.W. HAMMOND, AND R.D. MORRISON
}

\section{Abstract}

A study was conducted from 1971 through 1975 in a north central Oklahoma tallgrass prairie to determine effects of (1) different rates of 2,4-D on grass production in fair to good condition areas where forb production was low, (2) repeated applications of 2,4-D on grass and forb production, and (3) species composition and range site growing conditions on grass and forb production responses to 2,4-D application. Five rates 2,4-D (0.00, 0.28, 0.56, 0.84 , and $1.68 \mathrm{~kg} / \mathrm{ha}$ ) were applied in 1971 to determine their effects on grass production where forbs had been removed manually prior to spraying. Grass production increases equalled forb production decreases, regardless of whether forbs were reduced by 2,4-D or hand-weeding prior to 2,4-D application. From 1972 through 1975, the same 5 rates of 2,4-D were applied annually on four tallgrass prairie sites differing in range condition, past use, and soil factors. Site and annual growing conditions had more effect on grass production than did 2,4-D applications. There was no evidence of a stimulative growth effect by 2,4-D on grass production. All increases in grass production were accompanied by decreases in forb competition.

Conflicting reports exist as to whether increases in grass production after spraying with 2,4-D [(2,4-dichlorophenoxy) acetic acid] are due to reduced forb competition or a direct physiological growth stimulation. Most field studies base their conclusions on the amount of grass production increase and the amount of concurrent forb production decrease after 2,4-D is applied to all the vegetation present.

In the tallgrass prairie Elwell and McMurphy (1973) reported a 3-fold increase in grass forage for each unit of forbs removed using 2,4-D. Morrow and McCarty (1976) also noted that total herbage yield increased when forbs were killed.

Klingman (1956), however, found no increase in total herbage production. He reported an increase in production of desirable grasses equal to the decrease in forb production. Thilenius et al. (1974) in an alpine area and Thilenius et al. (1975) in a subalpine area also reported increased grass production about equal to the decrease in forb production after 2,4-D was applied.

Since the application of 2,4-D is an accepted and widespread range improvement practice in the tallgrass prairie, this study was designed to learn more about the effect of 2,4-D applications on grass production. Considering the possible influence of differences in rate of application, species composition, and growing conditions, experiments were conducted simultaneously on several different sites and continued for several years. Specifically the research attempted to determine effects of (1) different rates of 2,4-D on grass production in areas in fair to good condition where forb production was low, (2) repeated applications of 2,4-D production of grass and forb species, and (3) species composition and

\footnotetext{
The authors are professor of range science, professor of agronomy, range research technician, Department of Agronomy, and professor of statistics, Department of Statistics, Oklahoma State University, Stillwater 74078.

This research is a contribution of the Oklahoma Agricultural Experiment Station as Journal Article No. 3892.

Powell is at present with the Range Science Department, University of Wyoming, Laramie; Hammond's present address is Superintendent, Pahrump Experiment Station, Pahrump, Nevada 89041 .
}

range site growing conditions on grass and forb production response to 2,4-D applications.

\section{Study Area}

The experiment was divided into 2 separate studies. Study I was conducted during the 1971 growing season in the $S E 1 / 2$, Sec 11, T19N, RIW, Indian Meridian. Study II was conducted from 1972 through 1975 in the SE $1 / 2$, Sec 4 and SE $1 / 2, \operatorname{Sec} 3, T 19 N$, RIW, Indian Meridian. Both study areas are within the Lake Carl Blackwell watershed about 15 to $20 \mathrm{~km}$ north west of Stillwater, Okla., in the tallgrass prairie.

The climate of the area is continental with hot, humid summers and moderately cool, dry winters. The average number of frost-free days is 206 from early April to late October or early November. The average absolute maximum temperature is $40^{\circ} \mathrm{C}$ or higher June through September. The average absolute minimum temperature is $-20^{\circ} \mathrm{C}$ or lower for December through March.

Average annual precipitation is $820 \pm 250 \mathrm{~mm}$ with about $75 \%$ occurring during the growing sea son. The average monthly precipitation ranges from about $120 \mathrm{~mm}$ in May to $30 \mathrm{~mm}$ December-February. Average pan evaporation exceeds $250 \mathrm{~mm} / \mathrm{mo}$. June-August. Windspeeds are greatest in March $(230 \mathrm{~km} /$ day $)$ and least in August ( $115 \mathrm{~km} /$ day). The mean relative humditiy is 60 to $70 \%$.

The topography is rolling with 3 to $5 \%$ slopes on the ridges and upland areas. The vegetation is primarily tallgrass prairie with Cross Timbers woodland vegetation (especially Quercus spp.) on shallow, coarse-textured soils. Woodland vegetation along watercourses in the study area is described by George and Powell (1977). Grassland vegetation in the area is described by Broyles (1978).

Study I was conducted on a claypan prairie range site in lowgood range condition on Kirkland silt loam soil (fine, mixed, thermic Udertic Paleustoll). The area was revegetated naturally after being cultivated about 35 to 40 years prior to the study. During the 20 years prior to these investigations, the study area was moderately grazed by cows and calves.

Study II was conducted about $3 \mathrm{~km}$ northwest of the Study I area. The area for Study II was selected because of the variety of sites available for use. The 4 sites used in Study II are described in Table 1.

In general these sites represented loamy prairie and loamy bottomland range sites in fair to excellent range conditions. All sites had relatively low forb populations and consequently, low forb competition. Previous land use was varied but consistent for each site during the 5 to 10 years prior to the study. Species composition varied among the sites, but little bluestem (Schizachyrium scoparium), big bluestem (Andropogon gerardii), indiangrass (Sorghastrum nutans), gramas (Bouteloua spp.), western ragweed (Ambrosia psilostachya), heath aster (Aster ericoides), western yarrow (Achillea lanulosa), Louisia na sagewort (Artemisia ludoviciana), and showy partridgepea (Cassia fasciculata) were common on one or more sites. 
Table 1. Site factors of the four areas used in Study II.

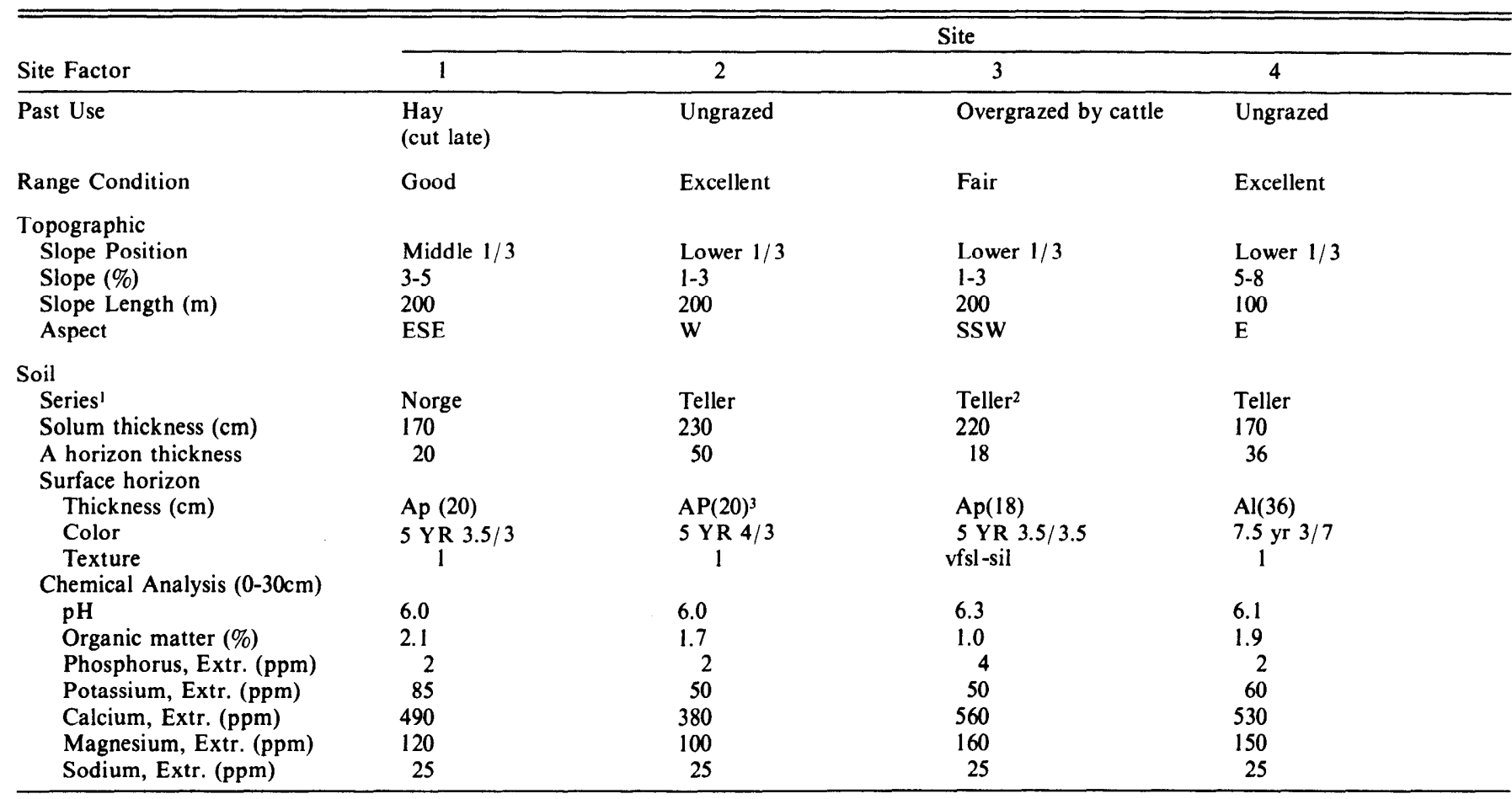

${ }^{1}$ Norge-fine-silty udic paleustolls; Teller-fine-silty over sandy, mixed, mesic type hapludalfs; Konawa-fine-loamy, mixed, thermic ultic haplustalfs.

${ }^{2}$ Teller-like gradational to Konawa-like; no mollic epipedon; subject to occasional flooding.

${ }^{3}$ Upland overburden.

\section{Methods}

\section{Study I}

A randomized complete block design with 3 replications was used for Study 1 . Treatments were in a factorial arrangement with 5 rates of 2,4-D application and 2 weeding treatments. Each of the 30 plots was $3 \mathrm{~m} \times 7.5 \mathrm{~m}$.

In early May, 1971, all forbs were removed by hand from the weeded areas. Then a butoxypropyl ester of 2,4-D (2,4dichlorophenoxy acetic acid) was applied at $0.00,0.28,0.56,0.84$, or $1.68 \mathrm{~kg} /$ ha rates to both weeded and unweeded areas. The 2,4-D was applied as a water emulsion with no surfactant or other additive by a small, portable $\mathrm{CO}_{2}$ boomtype sprayer calibrated to deliver $233 \mathrm{l} / \mathrm{ha}$.

In late August, species composition and production were determined using the weight-estimate (Pechanec and Pickford 1937) and double sampling (Wilm et al. 1944) methods. The live weight of each species was estimated in each of $4,0.5 \mathrm{~m}^{2}$ quadrats per plot. All live vegetation in one of the 4 quadrats was clipped at a $5-\mathrm{cm}$ stubble height, bagged, weighed, oven-dried at $65 \mathrm{C}$ and reweighed to determine the dry matter and estimation correction factors.

\section{Study II}

A randomized complete block design with 4 replications and 5 rates of 2,4-D application was used for each of the 4 sites in Study II. No areas were hand weeded in Study II.

The 2,4-D rates, plot size, and method of 2,4-D application were the same as described in Study I. Each area received the treatment in early May of 1972, 1973, 1974, and 1975 at about the same phenological state for key species. Each previous year's old growth was mowed at a 5-cm stubble height in early March of the following year and removed from the plots.

Methods used to determine species composition and production were the same as described for Study I. Sampling was done at or soon after peak production.
All data were subjected to analysis of variance using a splitsplit-plot analysis (Steele and Torrie 1980). Probability levels were determined for differences between means per source of variation. Those differences found to be significant at the 0.05 level (and at the 0.10 level in one case) were tested using the Least Significant Difference for 5 or fewer treatments or the Duncan's new multiple range test for 6 or more treatments (Steele and Torrie 1980). Computer analyses used the Statistical Analysis Systems (SAS76) software package by Barr and Goodnight (1976). All differences discussed are significant at the 0.05 level unless otherwise stated.

\section{Results and Discussion}

The first 2 years of the study, 1971 and 1972, were relatively dry, whereas 1973, 1974, and 1975 were relatively wet. The winter months of 1971 and 1972 were very dry with little or no precipitation falling during several months. Although rainfall in June and July, 1971, was much greater than average, only about $10 \mathrm{~mm}$ fell in August. Plant water stress was evident during vegetation sampling in late summer, 1971. Spring and summer rainfall in 1972 was more uniform than that in 1971; however, accumulative rainfall in 1972 was much below average until October.

Rainfall amounts in 1973, 1974, and 1975 were greater than average primarily because of above-average rainfall in spring and fall months. Growing conditions were consequently much more favorable during the latter part of the study.

\section{Study I}

Forb production in unweeded areas was decreased by spraying with 2,4-D (Fig. 1). This was accompanied by an increase in grass production. However, the increase in grass production was from 10 to $30 \%$ less than the reduction in forb production, resulting in a decrease in total herbage production. Hand weeding was more effective in reducing forb production than was 2,4-D. The increased grass production in the weeded plots was similar with all rates of $2,4-\mathrm{D}$ and similar to grass production in the unweeded 


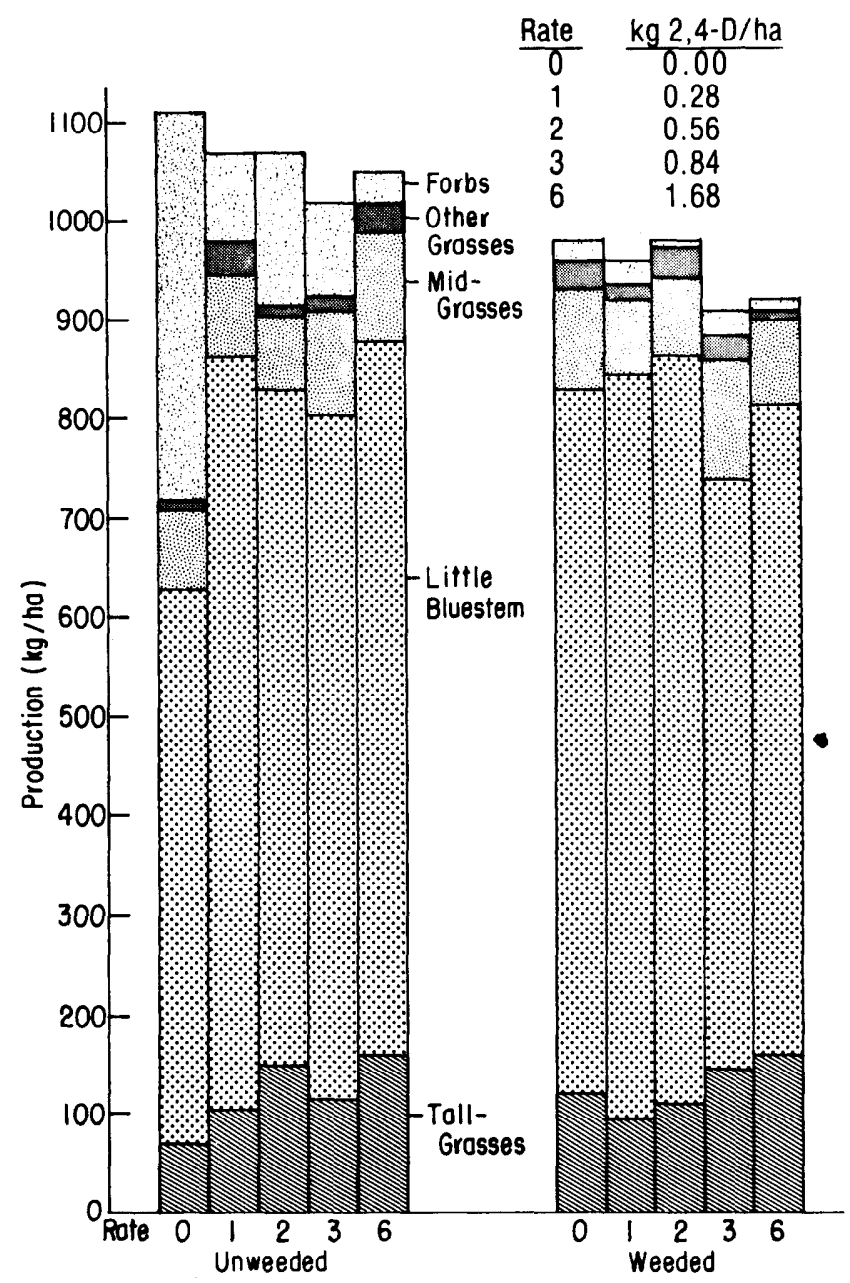

Fig. 1. Average (4 replications) species class production ( $\mathrm{kg} \mathrm{DM} / \mathrm{ha}$ ) for north central Oklahoma tallgrass prairie areas unweeded and weeded prior to spraying with 5 rates of 2,4-D, Study I. (LSD.05; Forbs (unweeded) $150 \mathrm{~kg} / \mathrm{ha}$ ).

plots sprayed with 2,4-D. Not only was there no direct effect on grass production with 2,4-D spraying, there was no observable difference in leaf color or other physical characteristics.

More than half the grass production in all areas was little bluestem. Little bluestem is a bunchgrass and often dominates natu- rally revegetated cropland. Little bluestem tends to be less responsive in terms of increased growth than tallgrasses when range improvement practices, such as fertilization, burning, and weed control, are applied.

Most of the tallgrass production was indiangrass, which is not unusual on previously cultivated land. Tallgrass production was about the same in all weeded areas indicating a lack of indiangrass response to 2,4-D application.

\section{Study II}

The analysis of variance used to determine probability levels for site, rate, and year main effects and associated interaction effects on species class production is shown in Table 2. In general differences between sites and between years had a significant influence on all species classes whereas rates of 2,4-D application influenced forbs more than grasses.

Total herbage production on Sites 1, 2, and 4 was similar (2830 to $2930 \mathrm{~kg} / \mathrm{ha})$, and much greater than on Site $3(2190 \mathrm{~kg} / \mathrm{ha})($ Fig. 2). Site 3 was dominated by little bluestem, which contributed about $75 \%$ of the grass production $(2030 \mathrm{~kg} / \mathrm{ha})$ and $68 \%$ of the total herbage production. On the other 3 sites little bluestem contributed from 25 to $40 \%$ of the grass production (2660 to 2730 $\mathrm{kg} / \mathrm{ha})$

Tallgrass production was relatively minor on Site 3, but provided 40 to $50 \%$ of the total herbage on the other 3 sites. Indiangrass dominated Site 1 and Site 2. Big bluestem was most common on Site 4 , the only site showing no signs of previous cultivation. Midgrasses were also most abundant on Site 4. Of these grasses, sideoats grama (B. curtipendula) was common only on Site 4, present in very small amounts on Site 3 and not found on Site 1 or Site 2.

Although forb production on all sites was relatively low, forb production on Site $1(270 \mathrm{~kg} / \mathrm{ha})$ averaged about twice as much as on other sites ( 100 to $160 \mathrm{~kg} / \mathrm{ha}$ ). About $30 \%$ of the forb production on Site 1 was from Lespedeza spp. Western ragweed and heath aster were present on all sites except Site 2, although these 2 species provided only 1 to $3 \%$ of the total herbage on any site. Showy partridgepea was the most common forb on Site 2, but provided only about $16 \%$ of the forb production and $1 \%$ of the herbage production. Site 2 had a heavy layer of ground litter and ungrazed indiangrass plants provided a closed community of tallgrasses.

\section{Rate Effect}

Forb production decreased as the rate of 2,4-D increased from 0.28 to $1.68 \mathrm{~kg} / \mathrm{ha}$ (Fig. 3). There was a corresponding increase in grass production that equaled the decreased forb production. This resulted in the total herbage production being equal regardless of the rates of 2,4-D.

Table 2. Analysis of variance used to determine probablity levels for Site, Rate and Year main effects and associated interactions in Study II. Probability levels are shown for 7 species classes.

\begin{tabular}{|c|c|c|c|c|c|c|c|c|}
\hline \multirow[b]{2}{*}{ Source of variation } & \multirow[b]{2}{*}{ df } & \multicolumn{7}{|c|}{ Species class } \\
\hline & & $\begin{array}{l}\text { Tall } \\
\text { grasses }\end{array}$ & $\begin{array}{l}\text { Little } \\
\text { bluestem }\end{array}$ & $\begin{array}{l}\text { Mid- } \\
\text { grasses }\end{array}$ & $\begin{array}{l}\text { Other } \\
\text { grasses }\end{array}$ & Grasses & Forbs & Herbage \\
\hline$\overline{\text { Total }}$ & 319 & - & - & - & - & - & - & - \\
\hline Site & 3 & .01 & .01 & .01 & .01 & .01 & .01 & .01 \\
\hline Rep (Site) $)^{1}$ & $12^{\Delta}$ & - & - & - & - & - & - & - \\
\hline Rate & 4 & .99 & .10 & .26 & .15 & .02 & .01 & .95 \\
\hline Rate $\times$ Site & 12 & .01 & .19 & .61 & .89 & .26 & .05 & .24 \\
\hline Rate $\times \operatorname{Rep}($ Site $)$ & $48^{\Delta}$ & - & - & - & - & - & - & - \\
\hline Year & 3 & .01 & .01 & .01 & .01 & .01 & .01 & .01 \\
\hline Year $\times$ Site & 9 & .01 & .01 & .01 & .01 & .01 & .01 & .01 \\
\hline Year $\times$ Rate & 12 & .90 & .65 & .64 & .94 & .94 & .01 & .98 \\
\hline \multirow{2}{*}{$\begin{array}{l}\text { Year } \times \text { Site } \times \text { Rate } \\
\text { Year } \times \text { Rep }(\text { Site }) \\
\quad+\text { Year } \times \text { Rate } \times\end{array}$} & 36 & .38 & .72 & .99 & .99 & .86 & .06 & .93 \\
\hline & & & & & & & & \\
\hline$\overline{\operatorname{Rep}(\text { Site) }}$ & $180^{\Delta}$ & - & - & - & $\ldots$ & - & $\ldots$ & - \\
\hline
\end{tabular}

'Rep within Site

${ }^{\Delta}$ Error term 


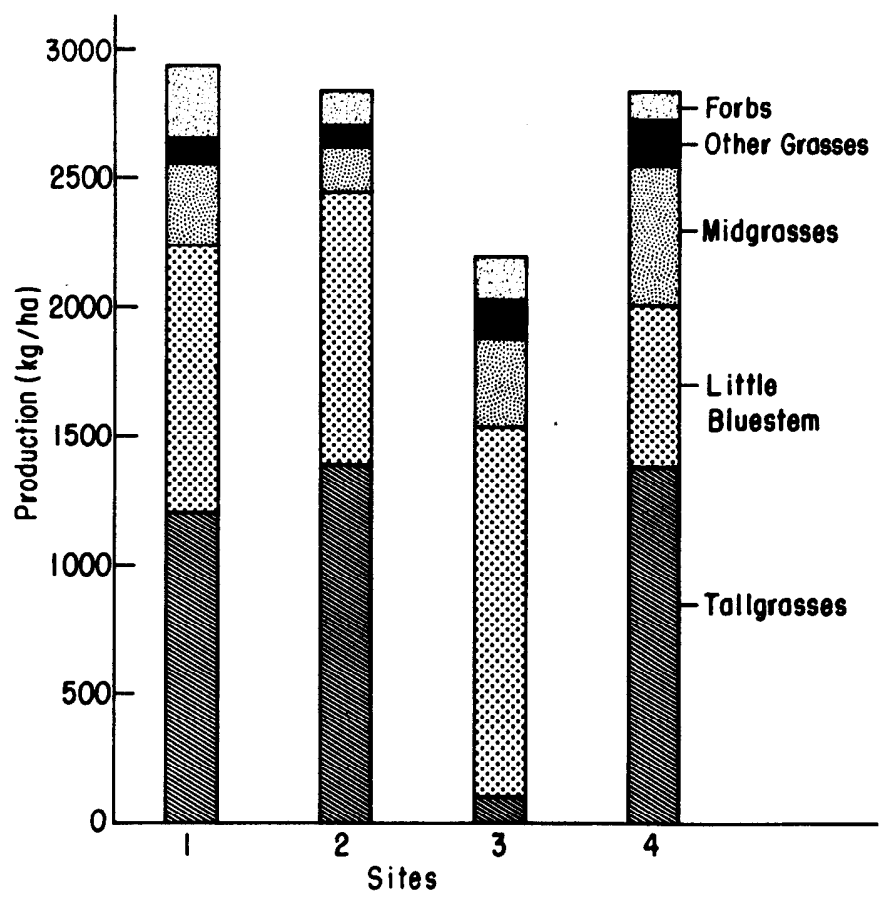

Fig. 2. Average (4 replications $\times 4$ years $\times 5$ rates) species class production ( $\mathrm{kg} \mathrm{DM} / \mathrm{ha}$ ) on 4 sites in the north central Oklahoma tallgrass prairie, 1972-1975. Study II. (LSD.05: Tallgrasses-550 kg/ha; Little bluestem-550 $\mathrm{kg} / \mathrm{ha}$; Midgrasses-190 kg/ha; Other Grasses- $\mathrm{P}<10$; Forbs-80 kg/ha).

Individual species of forbs contributed such low and inconsistent amounts of production that differences due to rate of 2,4-D application were not significant at the 0.05 or even 0.10 level of probability. Most forbs, however, showed declining trends in production with increased rates of 2,4-D application. Some differences in forb species production due to rates of 2,4-D application were masked by Rate $\times$ Year and Rate $\times$ Site interactions. These will be discussed later in this paper.

Little bluestem was the only individual grass species whose production was affected $(P<.08)$ by different rates of $2,4-\mathrm{D}$ application. Treated areas produced about $160 \mathrm{~kg} / \mathrm{ha}$ or $18 \%$ more little bluestem than untreated areas. Increased little bluestem production due to forb reduction by 2,4-D application was most consistent on Site 3 where it was dominant.

\section{Year Effect}

Differences in growing conditions in different years affected production of all 5 major species classes studied (Fig. 4). Production of each species class was generally lowest in $1972(670 \mathrm{~mm}$ annual precipitation) and highest in 1973 (1210 mm precipitation). Much of the total precipitation in 1972 fell in October, after the vegetation was mature. The October and November rains allowed plants to replenish root reserves and provided subsoil water for the 1973 growing season.

Tallgrasses appeared to respond sooner to good growing conditions than did the other grass or forb species classes. Tallgrass production almost doubled between 1972 and 1973. Little bluestem production increased between 1972 and 1973 but did not peak until 1974.

Midgrass production was lowest in 1974 and highest in 1975. The low rainfall in July 1974, just prior to vegetation sampling, probably influenced production of midgrasses. Summer growth of midgrasses and shortgrasses appea red to fluctuate more widely due to variable summer rainfall than did that of tallgrasses and little bluestem.

Forb production increased on all sites each year from 1972 through 1975 (Fig. 5). In 1972 forbs produced only $2.6 \%$ of the herbage. This increased to $3.5 \%$ in $1973,6.8 \%$ in 1974 and $10.5 \%$ in 1975. These areas were not grazed during the study period and nongrazing may have enhanced production of forbs.

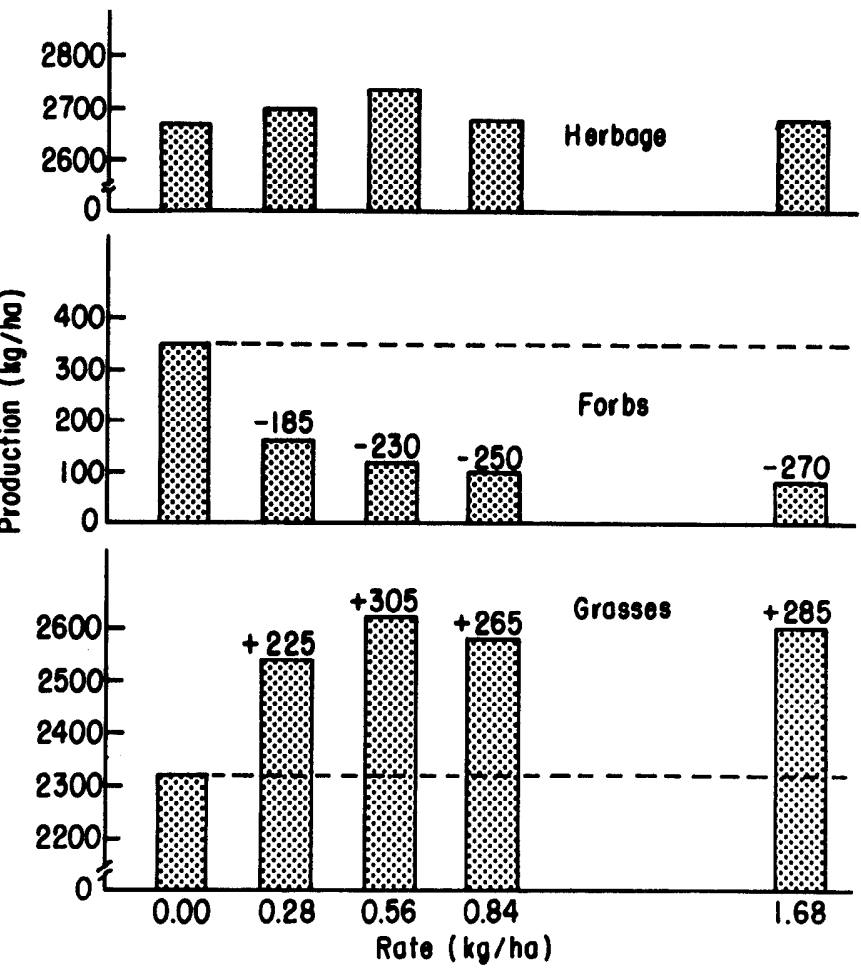

Fig. 3. Average (4 replications $\times 4$ sites $\times 4$ years) species class production ( $\mathrm{kg} \mathrm{DM} / \mathrm{ha}$ ) in north central Oklahoma tallgrass prairie sprayed with 2,4-D at 5 rates, Study II. (LSD.05: Herbage-P<.95; Forbs-70 kg/ha; Grasses-200 kg/ha).

A significant portion of the forb production in 1974 and 1975 was from lespedeza species which are tolerant to 2,4-D. Most of the lesperdeza production was on Site 1 and may have resulted from an accidental fire which burned across Site 1 in March, 1974. Fires frequently increase germination of legume seed (Clewell 1966, Martin and Cushwa 1966).

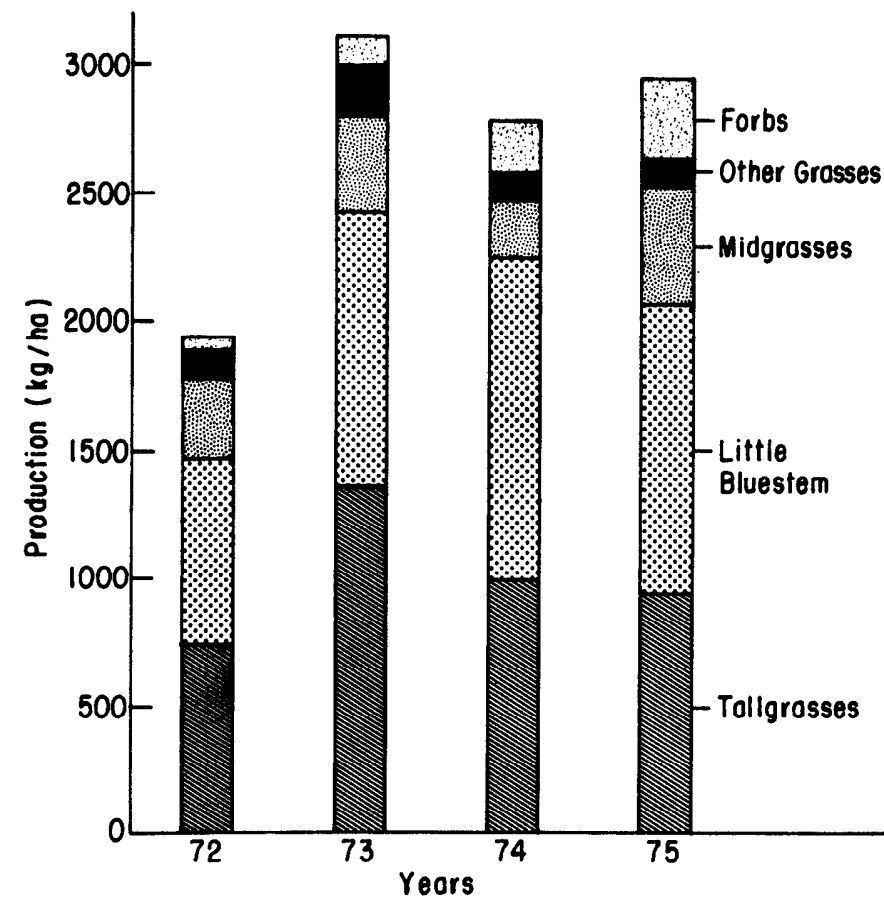

Fig. 4. Average (4 replications $\times 4$ sites $\times 5$ rates) species class production (kg DM/ha), 1972-1975, in the north central Oklahoma tallgrass prairie, Study II. LSD.05: Tallgrasses-140 kg/ha; Little bluestem-140 kg/ha; Midgrasses-70 kg/ha; Other Grasses-40 kg/ha; Forbs-50 kg/ha). 


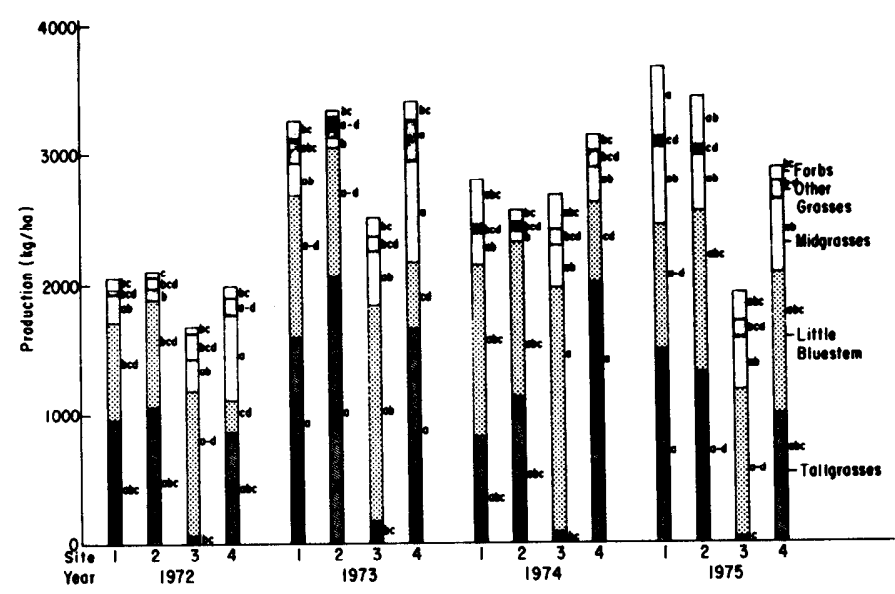

Fig. 5. Average (4 replications $\times 5$ rates) species class production $\mathrm{kg}$ $D M / h a)$ on 4 sites in the north central Oklahoma tallgrass prairie, 1972-1975, Study II. Values for the same species class followed by the same letter are not different at the 0.05 level of probability.

\section{Year $\times$ Site Effect}

Total herbage production varied widely among sites and years, ranging from $1670 \mathrm{~kg} /$ ha on Site 3 in 1972 to $3630 \mathrm{~kg} /$ ha on Site 1 in 1975 (Fig. 5). Site 1 and Site 2 produced about the same amount of herbage each year. This was usually equal to that on Site 4 and greater than that on Site 3. However, in 1974 herbage production on sites 3 and 4 was relatively high. This was attributed to the high production of little bluestem on Site 3 and high production of big bluestem on Site 4. Indiangrass production on Sites 1 and 2 was also lower in 1974 than in 1973 or 1975 . Big bluestem production was low and little bluestem production high on Site 4 in 1975 compared to the production on this site in earlier years.

Midgrass production was highest on Site 4 in 1972 and 1973 although the average midgrass production for all sites was highest in 1975 . Forb production increased in each succeeding year, but the greatest increase occurred in Site 1 in 1974 and 1975 and on Site 2 in 1975. Apparently the fire on Site 1 in March 1974 and the large rainfall amounts in May, 1974 and 1975, encouraged growth of forbs such as lespedeza and partridgepea.

Our results demonstrate that species production and species composition can vary greatly in tallgrass prairies. This capacity for change could be used to advantage in range improvement programs if the species requirements for growth and responses to management practices were better understood.

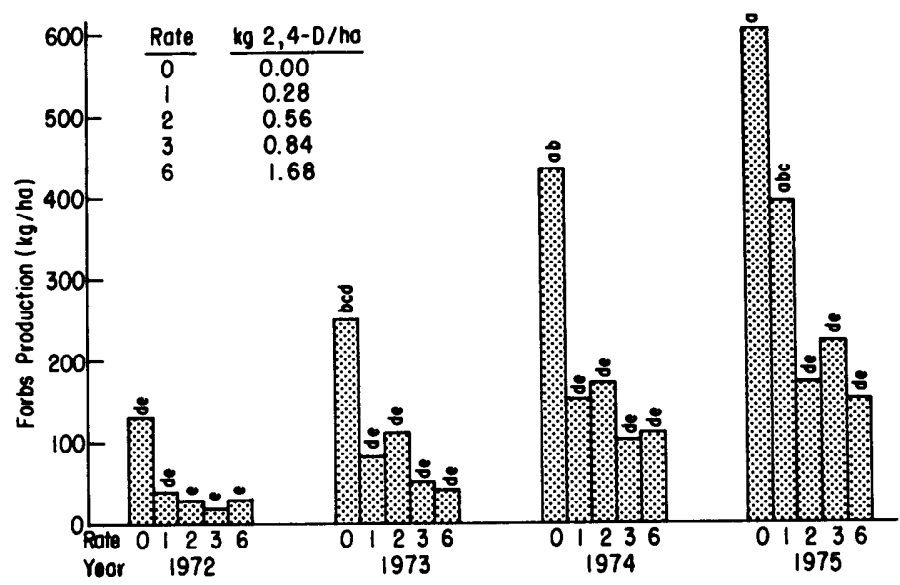

Fig. 6. Average (4 replications $\times 4$ sites) forb production $(\mathrm{kg} D M /$ ha) on north central Oklahoma tallgrass prairie sites, sprayed with 2,4-D at 5 rates, 1972-1975, Study II. Those values topped by the same letter are not different at the 0.05 level of probability.

\section{Year $\times$ Rate Effect}

Average forb production decreased with increasing rates of 2,4-D application. However, forb production increased with each succeeding year from 1972 through 1975. This may have resulted from the late winter mowing treatment reducing the dead vegetation. In the first 3 years of treatments all rates of 2,4-D application caused a 60 to $80 \%$ reduction in forb production and there was very little difference in forb production on any area receiving 2,4-D (Fig. 6).

In 1975, however, when forb production on untreated areas reached $600 \mathrm{~kg} / \mathrm{ha}$, the $0.28 \mathrm{~kg} 2,4-\mathrm{D} /$ ha rate produced only a $35 \%$ reduction in forbs. One factor influencing the reduced effect of the $0.28 \mathrm{~kg} /$ ha rate was the greater production and proportion of lespedeza and partridgepea in 1975. These species appear to be tolerant to low rates of 2,4-D application. Since most lespedeza species are desirable forage plants it may be possible to maintain or increase certain desirable for species while reducing less desirable species, such as western ragweed, with low levels of 2,4-D.

\section{Year $\times$ Site $\times$ Rate Effect}

Some of the Year $X$ Rate differences in forb production were caused by the effects of site conditions on species composition. Other differences appear to be related more to interactions between growing conditions for the same species and rates of 2,4-D application (Fig. 7).

Forb production on Site 1 was about the same as on other sites in 1972 and 1973. After Site 1 was burned in March 1974 and lespedeza increa sed greatly, forb production was greater on treated plots on Site 1 than on treated plots on other sites.

In 1975 partridgepea increased greatly on Site 2 . The lowest rate of 2,4-D application did not reduce forb production as it did on other sites in 1975 and other years.

In 1975 forb production on untreated areas was greatest on Site 3. Rainfall was greater than average in May, 1974. Rapid growth of forbs, such as ragweed and heath aster, on coarse-textured soil at
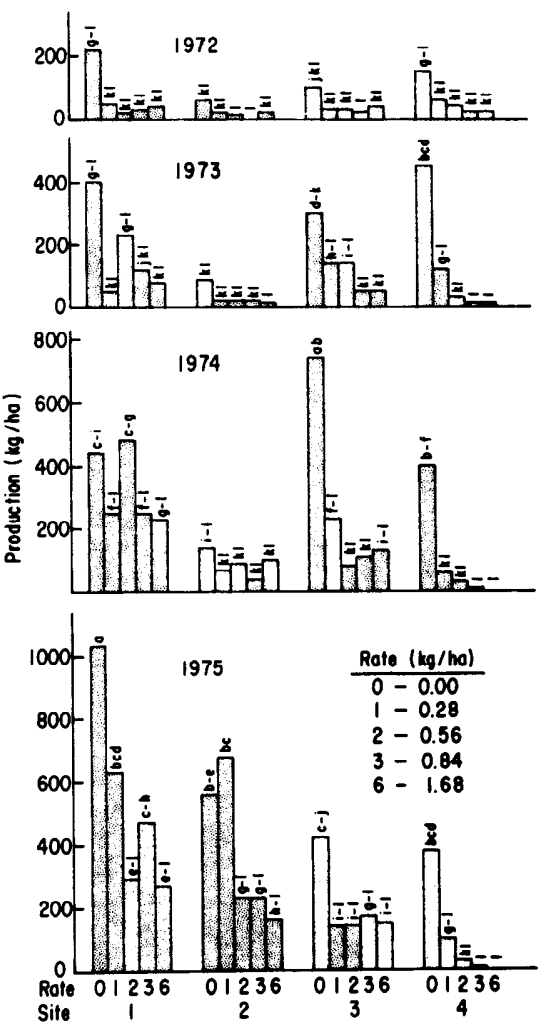

Fig. 7. Average (4 replications) forb production ( $\mathrm{kg} \mathrm{DM} / \mathrm{ha}$ ) on 4 sites in the north central Oklahoma tallgrass prairie sprayed with 2,4-D at 5 rates, 1972-1975, Study II. Those values topped by the same letter are not different at the 0.05 level of probability. 
the time of 2,4-D application may have increased susceptibility to the low rate of 2,4-D application on this site.

Site 3 and Site 4 forb production was dominated by ragweed and heath aster. Both of these species are relatively susceptible to 2,4-D, but the degree of susceptibility to higher rates of 2,4-D applications was greater on Site 4 than on Site 3. Site 4 growing conditions (e.g., 36-cm unplowed A horizon, $1.9 \%$ organic matter and loam texture) appeared to be more mesic and favorable for growth than those (e.g., 18-cm Ap horizon, 1.0\% organic matter, very fine sandy loam-silt loam texture) on Site 3 . If the same species are more susceptible to 2,4-D under more favorable site conditions and desirable forage plants are available to take advantage of the reduced competition, the greatest economic return from applications of 2,4-D will be on the most productive sites.

\section{Literature Cited}

Barr, A.J., and J.H. Goodnight. 1976. A user's guide to the statistical analysis system. Department of Statistics, N.C. State Univ., Raleigh, N.C. 329 p.

Broyles, P.J. 1978. Oklahoma tallgrass prairie species composition and production responses to rotation fertilization on different range sites. M.S. Thesis. Oklahoma State Univ., Stillwater. 70 p.

Clewell, A.F. 1966. Natural history, cytology, and isolating mechanisms of the native American Lespedezas. Tall Timbers Res. Sta. Bull. No. 6.
Elwell, H.M., and W.E. McMurphy. 1973. Weed control with phenoxy herbicides on native grasslands. Oklahoma Agr. Exp. Sta. Bull. B-706. 22 p.

George, J.F., and J. Powell. 1977. Deer browsing and browse production of fertilized American elm sprouts. J. Range Manage. 30:357-60.

Klingman, D.L. 1956. Weed control in pastures in the North Central Region. Weeds 4:369-75.

Martin, R.E., and C.T. Cushwa. 1966. Effects of heat and moisture on leguminous seed. Tall Timbers Fire Ecol. Conf. Proc. 5:159-75.

Morrow, L.A., and M.K. McCarty. 1976. Effect of repeated herbicide applications on green sagewort in north central Nebraska. J. Range Manage. 29:413-4.

Pechanec, J.F., and G.D. Pickford. 1937. A weight estimate method for the determination of range or pasture production. J. Amer. Soc. Agron. 29:894-904.

Steele, R.G.D., and J.H. Torrie. 1980. Principles and procedures of statistics, 2nd ed., McGraw-Hill Book Co., Inc. New York 633 p.

Thilenius, J.F., G.R. Brown, and C.C. Kaltenbach. 1975. Treating forbdominated subalpine range with 2,4-D: Effects on herbage and cattle diets. J. Range Manage. 28:311-5.

Thilenius, J.D. Smith, and G.R. Brown. 1974. Effect of 2,4-D on composition and production of an alpine plant community in Wyoming. J. Range Manage. 27:140-2.

Wilm, H.G., D.F. Costello, and G.E. Klipple. 1944. Estimating forage by the double-sampling method. J. Amer. Soc. Agron. 36:194-203.

\title{
Rangeland Plant Physiology
} edited by Ronald A. Sosebee

\author{
$\star 290$ pages \\ $\star$ illustrated \\ $\star$ soft cover perfect bound
}

$\star$ extensive bibliographies

$\star \$ 14.50$ postpaid

Of particular interest to all who study, manage, or simply admire plant life, the book is a valuable college text supplement and a reference source for range managers and technicians. Each chapter, authored by one or more authorities in the field, examines in considerable depth one aspect of plant physiology. Chapters include:

I. Gas Exchange and Photosynthetic Pathways in Range Plants; II Carbohydrate Translocation in Range Plants; III. Distribution and Utilization of Carbohydrate Reserves in Range Plants; IV. Water Relations of Range Plants; V. Salinity Effects on Range Plants; VI. Seed Physiology; VII. Plant Growth Regulators; VIII. Mineral Cycling in Rangeland Ecosystems; IX. Developmental Morphology and Management Implications.

\section{Society for Range Management 2760 West Fifth Ave. Denver, Colorado 80204}

